\title{
A tomada do palco: performances sociais de Mao Tsé-Tung a Martin Luther King, e a Black Lives Matter hoje
}

JEFFREY C. ALEKANDER

\section{Resumo}

Sociólogos da cultura vêm desenvolvendo, desde 2000, perspectivas teóricas e aplicações empíricas da teoria da performance social, que têm como ponto de partida a atualização da obra tardia de Durkheim, somada a elementos da virada estética e da teoria do drama. Essa abordagem refuta a interpretação econômica da ação desenvolvida por Marx, assim como a abordagem teórica da ação iniciada por Weber e continuada por Parsons. Neste ensaio, pretendo demonstrar como a teoria da performance social pode esclarecer a arte do protesto, tomando como exemplos a revolução comunista da China, o movimento americano por direitos civis de meados do século 20 , e os protestos atuais, majoritariamente afro-americanos, contra a violência policial nas cidades americanas. Entre a tradição de protesto afro-americana de meados do século vinte e as condições da população negra pobre das periferias das cidades do início do século 21, emerge o imenso desafio de forjar novos roteiros orientados à ação. São necessárias lideranças fortes, com talento dramatúgico e de direção. A fusão exitosa de público, roteiro e atores exige acesso aos meios de produção simbólica; interpretação empática das atuações em curso, por parte dos críticos; e suficiente influência ante os poderes relevantes para evitar repressão pelas forças do Estado. Esses diversos elementos foram postos em prática pelo movimento negro pelo fim da violência policial, que vem ganhando impulso desde 2012. Empregando novos meios digitais de produção simbólica, seus organizadores transmitiram narrativas, slogans e gestos persuasivos, provocando protestos massivos de afro-americanos e mudanças na opinião pública americana em relação à violência policial e ao racismo.

Palavras-chave: Teoria da performance social. Sociedade civil. Protesto. Movimentos sociais. Poder político.

*Yale University, Estados Unidos 


\section{Seizing the Stage: Social Performances from Mao Zedong to Martin Luther King, and Black Lives Matter Today ${ }^{1}$}

\section{Abstract}

Since the early 2000's, cultural sociologists have been developing theoretical understandings and empirical applications of social performance theory. This approach challenges the economic understanding of action developed by Marx as well as the action-theoretical approach that Weber initiated and Parsons continued. In this essay, I hope to demonstrate how social performance theory can illuminate the art of protest during China's communist revolution, the mid-century American civil rights movement, and the mostly African-American protest against police violence in American cities today. Between the black protest tradition of the mid- $20^{\text {th }}$ century and the conditions of poor black inhabitants of the inner cities in the early 21 rst century, there loomed the enormous challenge of forging new action-oriented scripts. These scripts have to be made to walk and talk, informing dramatic scenes that could appeal to, energize, and perhaps even unify citizen-audiences fragmented by race and class and demoralized by political fatalism. Strong leaders with performative gift are necessary. Successfully fusing audience, script, and actors require, as well, access to the means of symbolic production; sympathetic interpretation of ongoing performances by critics; and sufficient leverage vis-a-vis material power to block state forces from exercising repression. These disparate elements have been brought into place by the black movement against police violence that has gathered force since 2012. Deploying the newly digital means of symbolic production, its organizers projected compelling narratives, slogans, and gestures, triggering massive African-American protest and changing American public opinion regarding police violence and racism.

Keywords: Social performance theory. Civil society. Protest. Social movements. Political power.

\footnotetext{
${ }^{1}$ Tradução de Regina Vargas (UFRGS)
} 


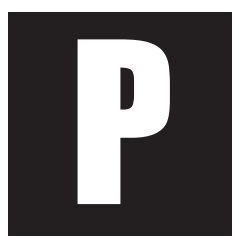

rotesto social não deveria ser conceitualizado de forma instrumental, como um processo que depende apenas de redes sociais e de recursos materiais. Esses fatores oferecem as condições limite para a ação simbólica, mas não determinam nem seu conteúdo, nem seus resultados. Para tomar o poder, é preciso, primeiro, ocupar a cena social (Eyerman, 2006).

Tomar a cena, produzir dramas sociais, e transmiti-los com êxito ao público - essas são conquistas culturais difíceis e contingentes, mesmo para aqueles que dispõem do poder hierárquico, autoritário. Para legitimar-se, um poder forte precisa sustentar performances igualmente fortes. Ao modo de produtores e diretores, os ditadores tentam criar atuações públicas impregnadas de ideologia. Falsos julgamentos públicos, tais como os Processos de Moscou projetados por Stalin na década de 1930, exibem confissões orquestradas, que são registradas por jornalistas e distribuídas em gravações e filmes. Convocações rigorosamente coreografadas, ritualísticas, mitopoéticas, para a projeção de líderes, como os comícios nazistas de Nuremberg em 1933, são esteticamente reconstruídas como eletrizantes para as dezenas de milhares de devotos nazistas presentes, e projetadas por cineastas como Leni Riefenstahl, em seu Triunfo da Vontade, para milhões de potenciais membros do público externo.

$\mathrm{Na}$ medida em que os regimes políticos, sejam eles autoritários ou democráticos, permitam que o poder seja desafiado com alguma facilidade, mais difícil será, proporcionalmente, monopolizar o cenário social. Em contextos sociais mais pluralistas, os elementos que o protesto social precisa reunir para produzir performances impactantes, e para projetá-las de modo a criar vínculo com seus públicos, encontram-se separados (Alexander, 2004). Para reintegrar esses elementos, as performances de protesto precisam ser engenhosamente montadas começando do zero, 
da base para o topo. Súplica e inspiração, dramas genuínos e francos tornam-se fundamentais. A mediação de condições extra-performáticas recursos interpretativos, materiais e demográficos - tornam-se igualmente importantes.

O movimento afro-americano por direitos civis constituiu um drama social com décadas de duração. Ele narrou e tornou visível o sofrimento social crônico, pontuando esta história com episódios de aguda e dolorosa tensão social. Se Martin Luther King é, hoje, considerado por muitos (Branch, 1988) como a mais importante figura americana do século vinte, não é apenas por ter sido um líder político e um visionário; ele foi também um excelente dramaturgo. King monopolizou a cena pública com mais eficácia que qualquer outra figura na história americana moderna. Ele instruiu seus seguidores afro-americanos em táticas não violentas e montou a coreografia de seus protestos de forma tão provocativa que as ações do movimento geraram sistematicamente respostas violentas e repressivas, as quais King, por sua vez, utilizou para moldar a resistência pública. Os dramas de King, de sacrifício e redenção, foram espalhados pelas telas de TV e manchetes de jornais americanos. Os brancos do Norte identificaram-se com o sacrifício do movimento e experimentaram uma catarse quando as massas negras triunfaram. Essa poderosa dramaturgia pública inverteu o poder do estado, e replicações de suas dramatizações não violentas da violência anticívica continuaram a ocorrer até os dias de hoje.

\section{Nota sobre a Teoria da Performance Social}

Desde o início dos anos 2000, sociólogos da cultura vêm desenvolvendo perspectivas teóricas e aplicações empíricas da teoria da performance social. Essa abordagem refuta a interpretação econômica da ação desenvolvida por Marx, assim como a abordagem teórica da ação social 
iniciada por Weber e à qual Parsons deu continuidade. Émile Durkheim, sobretudo em sua fase tardia, é uma referência basilar para a teoria da performance (Alexander; Smith, 2005), que incorpora também elementos da virada estética de Clifford Geertz (Alexander et al., 2011), e da teoria do drama de Victor Turner (Edles, 1998; Smith; Howe 2015), bem como dos estudos contemporâneos da performance, iniciados por Richard Schechner (2002). Além de conceitualizar este modelo macrossociológico da performance social, a "pragmática cultural" tem sido empregada para explorar uma grande variedade de situações empíricas, desde campanhas presidenciais (Alexander, 2010; Mast, 2012; Alexander; Jaworsky, 2014) e a Primavera Árabe (Alexander, 2011a), ao terrorismo e a Rebelião de Bacon (Reed, 2013) e a Guerra do Iraque (Alexander, 2011b); do processo de Verdade e Reconciliação da África do Sul (Goodman, 2016), às demandas de povos nativos por justiça social (Woods, 2016). No ensaio que se segue, espero demonstrar como a teoria da performance social pode esclarecer a arte do protesto durante a revolução comunista da China, o movimento americano por direitos civis de meados do século 20, e os protestos atuais, majoritariamente afro-americanos, contra a violência policial nas cidades americanas.

\section{Protestos revolucionários na China do século 20}

Movimentos sociais revolucionários anunciam que seu triunfo final é inevitável e, para os teóricos radicais, essa inevitabilidade é determinada pela força inelutável do interesse material. No entanto, no cerne dos movimentos revolucionários, a história é bem diferente. Eles são engenhos dramatúrgicos. Deixemos Marx com sua pretensão de que a revolução responde meramente a interesses objetivos, e sua descrição dos trabalhadores como protocientistas que seguem planos racionais e instrumentais. 
Lenin compreendia melhor. Ao atacar a falácia do economicismo, Lenin (1966 [1902]) colocou a ideologia no centro da mobilização revolucionária, organizando o bolchevismo como um partido ativo, pragmático, hierárquico, a serviço das ideias socialistas. Inspirado em Maquiavel, Gramsci (1959) apelidou o Partido Comunista de "o príncipe moderno". Em 1917, quando a revolução de Lenin triunfou, Gramsci (ibid.) publicou uma manchete ambígua no Avanti, jornal revolucionário italiano que ele editava: "Revolução contra o Capital" - sugerindo ironicamente que a teoria científica de Marx jamais poderia tê-la previsto. Gramsci sabia que a revolução na Rússia tivera sucesso não em razão das leis do capital, mas devido ao poder dramatúrgico do partido bolchevique.

\section{O contexto textual e seus limites}

Em sua radical reinterpretação da estratégia maoísta das décadas que precederam a revolução chinesa, Revolutionary Discourse in Mao'sRepublic, David Apter e Tony Saich transformaram essa linha de pensamento cultral marxista numa abordagem pós-estruturalista. Afastando-se de uma concepção reducionista, racionalista, da ideologia, rumo a uma interpretação geertziana, densamente semiótica, eles definem o organizador revolucionário como um contador de histórias, "um agente com uma habilidade especial de tirar o peso da narrativa dos ombros do indivíduo, permitindo-lhe compartilhá-la com outros [de modo que] a história passa a pertencer à comunidade discursiva" (Apter; Saich, 1994, p. 75). Cronista mestre da revolução chinesa, Mao Tsé-Tung selecionou "mitos, histórias, textos e ditames" das tradições chinesas e ocidentais, extraindo "das terríveis circunstâncias e condições de vida que prevaleciam na China" a visão de uma "república utópica" (ibid., xi). Com essa visão, Mao "pôde refratar e produzir um campo de forças, no epicentro do qual ele se torna um professor" (ibid., p. 298). 
Apter e Saich são manifestamente antimaterialistas e anti-"ator racional", mas sua narrativa culturalista do processo revolucionário tem alcance limitado. Sua análise do discurso político apresenta a revolução chinesa como uma "criação exegética". No entanto, ver esse evento extraordinário meramente como "materialização explícita de uma estrutura de ideias" (Apter; Saich, 1994, p. xv) é ignorar os desafios performativos que precisam ser enfrentados em tempo real, o complexo processo de representar ideias e conseguir um público que acredite nelas. "Para que as histórias sejam compartilhadas com outros", reconhecem Apter e Saich, "é preciso que as pessoas queiram ouvir" (ibid., p. 75), mas a questão é justamente definir como levar as pessoas a quererem ouvir. Simplesmente sugerir que "as próprias palavras se tornaram performativas" nada esclarece, deixa-nos diante da caixa preta estritamente linguística de Austin, na qual a performatividade é alcançada com a própria fala. O processo dramatúrgico que compõe o cenário, o processo de direção que organiza as cenas, a criatividade habilidosa dos atores ou a falta dela, o desafio organizacional e simbólico de gerar uma percepção de fusão contínua entre público, atores e roteiro - tudo isso precisa ser concebido. Mao, sem dúvida, possuía uma capacidade de "comunicar aos ouvintes um sentimento de acesso privilegiado à sabedoria interpretativa de uma mente ativa" (ibid., 85), mas o processo de comunicação, o sentimento de acesso privilegiado, e até mesmo a atribuição de sabedoria - tudo isso requer atenção.

Apter e Saich oferecem um vislumbre promissor da caixa preta da dramaturgia, quando situam a narrativa de Mao nas cavernas de Yan'an, onde o movimento comunista chinês se escondeu após sua "Longa Marcha" para escapar do Guomindang, em 1937-38. Narrando as histórias e escrevendo os textos, [Mao] faz-se parte integrante do processo. Tudo o que está associado à sua pessoa também se torna significativo - os cabelos longos, os dedos longos, as roupas largas, o modo simples de se expressar, o fato de, ao mesmo tempo, ser um homem do povo e um intelectual. 
[Mao] preparou-se cuidadosamente para projetar apenas a imagem que queria (Apter; Saich, 1994, p. 301).

No entanto, Yan'an acaba sendo retratada simplesmente como "um espaço semiótico" e Mao como um líder "detentor único de um discurso inversivo ${ }^{2}$ capaz de gerar apoio público", um "sistema interior de códigos, símbolos e ícone"que se revelou "capaz [de] unificar uma comunidade diversa" (Apter; Saich, 1994, p. 69). Contudo, o discurso, por si só, seria suficiente para unificar uma comunidade fragmentada e desalentada? O que, de fato, ocorreu nas cavernas de Yan'an? Que fator possibilitou o desenvolvimento do processo de revivificação ideológica? "Utilizando metáforas e metonímias, Mao cria um código", argumentam Apter e Saich, "que habilita a narrativa a dotar gestos, atos, vestimenta, moradia e, acima de tudo, linguagem e letramento com o poder dos significantes" (ibid., p. 99). Mas muito mais deve ter estado envolvido - gestos e movimentos improvisados, criativos, adereços e encenações, interpretações oficiais e dissidentes, plateias indiferentes e silenciosas, mas também gritos de prazer.

O fato de "um indivíduo ter-se tornado assimilado em uma comunidade discursiva" (Apter; Saich, 1994, p.182) é certamente um bom indicador do êxito pragmático-cultural - mas o que, especificamente, tal indicador mede? Precisamos saber como se realiza, na prática, a fusão entre orador e audiência. Não basta sugerir que "uma pessoa absorveu e internalizou o ritual" (ibid.). O que conta, empírica e heuristicamente, é como uma performance contingente e instável passa a ser considerada um ritual absorvedor, iterativo e unificador. Para que os textos sejam interiorizados, a atuação precisa ser convincente. Apter e Saich mencionam "a afirmação dos revolucionários de que tanto a dialética [marxista] como o sistema de ideias [maoísta] sempre estiveram presentes, uma realidade duradoura à espera de ser percebida" (ibid., p. xv). Reivindicações de verdade, contudo, devem ser efetivamente satisfeitas.

${ }^{2}$ [NT] No original: inversionary 
A autenticidade não é uma coisa previamente existente, à espera de ser percebida; é sim algo concedido por uma plateia motivada. Performance é mais do que uma simples questão de "pessoas repassando o texto, interpretando suas experiências e expressando-se por meio de discursos públicos que vinculam emissor e destinatário" (Apter; Saich, 1994, p. 224). Criar vínculo entre orador e audiências é o objetivo das performances. Apter e Saich fazem referência a termos como "simulacro" e "espetáculo" (ibid., pp. 130-31, 388 n. 31) para identificar atos de discurso ideológico persuasivo, mas esses conceitos burlam a intrincada textura da performance social; eles não os explicam.

Performance em teoria e na prática

As pesquisas acadêmicas sobre a revolução chinesa só lograram acertar o passo, depois de os estudos sobre a performance terem aberto a caixa preta da teoria do discurso, definindo o espaço entre significante e significado. "Embora as ciências sociais já viessem experimentando sua virada cultural há mais de uma geração", escreve Elizabeth Perry (2012), em seu desbravador estudo Anyuan (Ho, 2015), [a pesquisa] "é, muitas vezes, conduzida como análise de discurso, em que escritos, discursos, filmes, festivais e outros materiais comunicativos são tratados ... como textos desagregados" (Perry, 2012, pp. 4-5). O que essa abordagem deixa "sem resposta", ela argumenta, "é a questão de como os revolucionários lograram introduzir mensagens e métodos tão radicalmente novos, de modo a serem compreendidos por público" (ibid.). Definindo esse processo como "posicionamento cultural", Perry enfatiza que isso requer um "esforço ativo", e que "depende tanto das habilidades do mensageiro quanto do conteúdo e da sintaxe da própria mensagem" (ibid.)³.

\footnotetext{
${ }^{3}$ Apesar dessas evidências, nem Perry nem os demais pesquisadores cujo trabalho utilizo nesta seção baseiam seus argumentos na virada performativa. Em Anyuan, Perry (2012) apresenta seu principal termo teórico, "posicionamento cultural", como indicativo dos esforços revolu-
} 
No início da década de 1920, a cidade mineira do sul China, Anyuan foi cenário do primeiro grande êxito organizacional do Partido Comunista Chinês. Mao Tsé-Tung visitou Anyuan pouco depois da fundação do Partido. Ao chegar à cidade "segurando uma sombrinha de Hunan feita de papel encerado e vestindo uma túnica mandarim azul longa, do tipo usado por professores", relata Perry (2012, pp. 48-51), "causou impacto profundo nos trabalhadores". Pareceu-lhes que a indumentária de Mao destoava totalmente de sua pauta revolucionária. A longa túnica mandarim azul projetava a "visão de um intelectual privilegiado", um personagem que incorpora "a separação confucionista entre trabalho mental e manual", em lugar de alguém "desejoso de interagir com os humildes mineiros de carvão". Em contraste com sua roupa dissonante, a linguagem usada pelo personagem de Mao era muito mais adequada. "Graças à sua origem rural e dialeto coloquial", registra Perry, Mao "logrou dialogar facilmente com os trabalhadores - a maioria dos quais compartilhava sua origen Hunan". Quanto à vestimenta equivocada, Mao demonstrou aprender rápido. Ao fim de uma semana de imersão, ele havia reestruturado a roupa de seu personagem para encaixar-se melhor na cena local: "Ao final da semana, ele havia trocado seu traje acadêmico por calças, mais adequadas às incursões nas minas" ${ }^{4}$.

cionários chineses para concretizarem a ideologia marxista no contexto mais tradicional da cultura chinesa, e, em um trabalho anterior, também amplamente conhecido, Perry (2002) empregou um conceito sociológico-cultural de "manejo da emoção" para descrever uma intervenção histórica igualmente performativa em sua estrutura. Da mesma forma, tanto Yung-fa Chen quanto Sun Feiyu - cujos trabalhos utilizo adiante para aprofundar a abordagem performativa - descrevem suas próprias contribuições como reveladoras da "importância das dimensões psicológicas na política do PCC" (Chen, 1986, p. 100) e em termos de "tradições da psicanálise clássica e da fenomenologia - Sigmund Freud, Herbert Marcuse, Hannah Arendt, Michel Foucault e Paul Ricoeur" (Sun, 2013, p. 5). Em outras palavras, o movimento teórico que estou delineando aqui, de uma análise cultural pós-estruturalista, para uma orientada à performatividade, é minha própria interpretação do marco teórico-analítico que informou esses estudos recentes, não a dos autores citados.

${ }^{4}$ Duas décadas depois, nas palestras de Mao no Fórum sobre Literatura e Arte de Yenan, ele possivelmente recordava essa mudança de indumentária, quando insistiu que, para "assegurar que literatura e arte se adaptem à máquina revolucionária", os artistas do PCC precisam estar mais atentos à"questão do público" (Zedong, 1942, p. 3). "Uma vez que o público para nossa 
Em novembro de 1921, após completar essa missão exploratória, Mao enviou Li Lisan, seu jovem protegido comunista, a Anyuan para começar a organizar um movimento sindical local. Enquanto Mao havia trajado seu personagem com as vestes modestas do asceticismo revolucionário, Li via as coisas de outro modo. Ele "desfilava abertamente pela encardida cidade mineirade Anyuan, vestindo túnica mandarim longa ou em elegante traje ocidental e gravata, de forma a atrair a atenção" (Perry, 2012, p. 61). No entanto, o "estilo extravagante" de Li mostrou-se tão "cativante para os trabalhadores" quanto a aparência mais recatada de Mao. Um detalhe do traje de Li destacava-se particularmente -"o prendedor de metal brilhante (adquirido na França) que ostentava em seu peito". O distintivo "gerou boatos persistentes sobre Li Lisan ser invulnerável às espadas e às balas", diz Perry, acrescentando que o organizador comunista "nada fez para desmenti-los" (ibid). Os acessórios tinham uma função performativa, ligando a ideologia de Li, que poderia parecer estrangeira, a um conto popular chinês amplamente apreciado. A insígnia brilhante parecia fazer "referência ao irmão mais velho dos dragões imperadores, cuja autoridade repousava sobre sua reputação de poderes sobrenaturais", explica Perry. Ao utilizar esse adereço, "Li Lisan estimulava a crença de que desfrutava da proteção mágica de 'cinco países estrangeiros', outorgada durante suas viagens ao exterior" (ibid).

literatura e arte consiste de trabalhadores, camponeses e soldados e de seus quadros", sugeriu Mao, "surge o problema de entendê-los e conhecê-los bem" (ibid). Falando da desconexão entre as elites culturais e as massas, Mao afirmou que "os pensamentos e sentimentos de nossos escritores e artistas devem fundir-se com os das massas", recomendando que "para alcançar tal fusão, eles deveriam diligentemente aprender a linguagem das massas" (Zedong, 1942, p.4, itálico acrescentado). Mas "se você quiser ser compreendido pelas massas", advertiu Mao, deve "passar por um longo processo de moderação". "Aqui, posso mencionar minha própria experiência de como mudaram meus sentimentos. Comecei a vida como um estudante, [e] senti que os intelectuais eram as únicas pessoas decentes [e] que trabalhadores e camponeses eram grosseiros. Vestindo roupas de outros intelectuais [,] eu não usaria roupas pertencentes a um trabalhador ... Mas depois que me tornei um revolucionário e vivi com trabalhadores, mudei completamente" (ibid.). 
Li, no entanto, fez mais do que apenas assumir esse papel. Ele tratou de roteirizar seus esforços de organização no estilo dramático do ritual Hunan tradicional. Muito cedo, ficou evidente que os comunistas tinham algo completamente diferente da pedagogia tradicional -fosse da literatura confucionista (wen) ou das artes marciais $(w u)$.

O jornalista norte-americano Edgar Snow argumentou que "não havia arma mais poderosa de propaganda no movimento comunista do que as trupes de teatro dos Vermelhos" (Snow, 2007 [1938]). Snow observou que "quando os Vermelhos ocupavam novas áreas, era o Teatro Vermelho que abrandava os temores do povo, passava noções rudimentares sobre o programa dos Vermelhos e disseminava ideias revolucionárias para ganhar a confiança do povo" (Snow, 1963, pp. 123-24, citado em Perry, 2012, pp. 113). Autodeclarado torcedor-mor da revolução chinesa, com seu relato, Snow passa a ideia equivocada de fácil êxito performativo. Pesquisando documentos internos do partido, o historiador Yung-fa Chen refuta essa ideia, afirmando que o campesinato chinês era um público difícil de dobrar. Séculos de ensinamento confuciano atribuíram aos camponeses "uma tolerância à pobreza e à injustiça equivalente a uma devoção inquestionável à harmonia e à passividade" (Chen, 1986, p. 173). Os camponeses eram conservadores, precisavam ser convencidos para tornarem-se revolucionários.

Como demonstra Feiyu Sun em seu Social Suffering and Political Confession, de 2013, foi essa atitude relutante e refratária dos públicos camponeses que desencadeou a campanha "Expressar a amargura" do PCC ${ }^{5}$. A estratégia começou com Fan Pin Wen Ku -“visitar famílias pobres, investigar seus sofrimentos" (Sun, 2013, pp. 35-ss.). As equipes de traba-

\footnotetext{
${ }^{5}$ A capacidade da Sun de documentar a estratégia culturalmente pragmática do PCC apoia-se no acesso a documentos inéditos e intrapartidários, muito mais abertos com relação aos esforços e obstáculos performativos do que aos documentos de propaganda emitidos para consumo público. Chen (1986, p. xix) compara explicitamente documentos internos e externos. Perry também se baseia principalmente em fontes anteriormente não publicadas.
} 
Iho do PCC entravam nas aldeias camponesas levando consigo o que Sun chama de "técnica de experiência". Eles visitavam famílias pobres, sondando suas vidas pessoais. Não se tratava de mera questão de perguntas e respostas livres; a violência simbólica estava envolvida e a ameaça de violência física não estava descartada.

Para evitar o risco, percebido e real, de serem classificados como reacionários, os aldeões tinham de apresentar à equipe uma narrativa pessoal de seu sofrimento como camponeses pobres ou contratados. Se essa narrativa de sofrimento e opressão experimentados fosse suficientemente convincente para superar o forçoso ceticismo da equipe de trabalho e dos quadros, eles seriam recompensados com a classificação de "bom camponês" (Sun, 2013, p.36). Manifestamente, essas visitas tratavam de ideologia, de exercícios pedagógicos visando à reestruturação da cognição. "O objetivo declarado desse diálogo", escreve Sun, "era ensinar aos camponeses como refletir sobre suas condições e identidade e interpretá-las através de uma linguagem narrativa preparada, que a ideologia política do PCC propiciava" (id., p. 37).

A pretensão subjacente da Fan Pin Wen Ku, no entanto, era dramatúrgica - visava induzir a experiência do "expressar a amargura", ou Suku. Segundo documentos oficiais, Suku referia-se a compartilhar "oralmente uma história pessoal sobre ser perseguido por classes inimigas [...] com o propósito de inspirar nos ouvintes o ódio de classe [e] reafirmar a própria posição de classe" (Chen, 1952, p. 331 citado em Sun, 2013, p. 2). O próprio Sun fornece uma definição mais elaborada, dramatúrgica:

Suku é a prática de confessar o sofrimento individual em um contexto político e em um fórum coletivo. Em chinês, o termo Suku significa contar sobre o próprio sofrimento, ou despejar a própria amargura publicamente. Su significa dizer, falar, derramar ou confessar, enquanto o termo Ku significa amargura, dor e sofrimento (Sun, 2013, p. 2). 
Um dos organizadores do partido descreveu o Suku como "o detonador do movimento de massa Fanshen" (Sun, 2013, p. 46). Na épica campanha por reforma agrária do PCC, Fanshen (literalmente, "virar do avesso") referia-se a um complexo esforço organizacional que levou os camponeses do fatalismo tolerante ao ativismo irado. As dramatizações organizadas pelos quadros do partido, com frequência produziam catarse política em escala massiva. Um relatório interno intitulado "Assembleia Suku de Camponeses Pobres", preparado em 1947, descrevia o ocorrido durante o movimento de Reforma Agrária, quando "cada distrito começava a praticar Suku" (ibid., p. 47). Apesar da autopromoção e de cifras enganosas, o relatório ilustra de forma impressionante as pretensões performativas dos quadros, dando indícios da escala do êxito dramático do Suku.

Embora essa discussão sobre o Suku esteja focada em seu desdobramento performativo antes da revolução de 1949, a mesma estrutura dramatúrgica serviu de poderosa ferramenta organizativa, com a qual o maoismo procurou moldar sentido e emoção entre as massas também depois da revolução. A Revolução Cultural da década de 1960, por exemplo, foi alimentada pela campanha "recordar a amargura", que tratava os episódios pré-revolucionários de expressação da amargura, não como performances, mas como relatos objetivos.

A amargura passada tornou-se não só articulação entre memórias individuais e coletivas, como também envolveu rituais e performances e, assim, logrou incorporar-se às instituições mais amplas da propaganda e da cultura popular chinesa ${ }^{6}$. Consequentemente, todas as representa-

\footnotetext{
${ }^{6}$ Durante a revolução cultural, as "óperas revolucionárias", escritas e produzidas por Jiang Qing, atriz célebre e ativista política que se tornou esposa de Mao em Yan'an, em 1939, substiruíram as óperas tradicionais e desempenharam um importante papel de propaganda. Apesar de seu enorme poder politico nessa época, há pouca evidência de que a experiência teatral de Qing tenha contribuído para a performatividade da política revolucionária chinesa em sua concepção mais ampla, nas décadas anteriores (Terrill, 1984). Encenar uma peça teatral é uma coisa, encenar performances sociais é outra bem diferente, embora, historicamente, as duas com frequência se entrecruzem. Mao Tsé-Tung tinha um dom performativo para a política, embora jamais tivesse escrito ou atuado para o teatro.
} 
ções da velha sociedade foram dissociadas das "realidades objetivas" e tornaram-se "realidades representacionais" (Wu, 2014, p. 247).

Os chineses conseguiram fazer a revolução, não porque seu Partido Comunista tenha fornecido informações verídicas que atendessem a interesses de classe objetivos, mas sim porque forjou uma arte revolucionária de protesto, que mesclava produtores, roteiros, atores, cenas e plateias. O drama revolucionário pode ter parecido emanar realismo e coerência, mas operava para combinar poderes estético e moral de forma a tornar-se sublime (Burke, 1990 [1757]).

\section{Protestos por direitos civis na América de meados do século XX}

Embora as organizações revolucionárias precisem ser engenhosas, em geral dispõem de instrumentos de poder coercitivo, via controle estatal ou partidário, de modo que a violência simbólica "agrega valor" ao potencial dramático dos roteiros ideológicos. Protestos de origem popular, nascidos de movimentos relativamente fracos, não dispõem dessa vantagem performativa. Seu êxito, portanto, torna-se muito mais difícil de sustentar.

Consideremos, por exemplo, o movimento afro-americano por direitos civis dos anos 1950-60. Um século antes, a Guerra Civil (1861-65) abolira a escravidão, mas, com o fim da Reconstrução dos Estados Unidos, uma década depois da vitória nortista, ficou impedida uma maior emancipação da população negra. Os negros do sul permaneceram enclausurados em um sistema de castas, e mesmo a crescente população negra do norte dos Estados Unidos continuou estigmatizada e destituída de poder. Nos anos 1950 e 1960, um extraordinário movimento social desafiou esse sistema de dominação, alcançando um surpreendente triunfo, embora parcial. 
Nas últimas décadas, os cientistas sociais tendem a interpretar o movimento por direitos civis como uma luta pelo"poder nu” (Morris, 2007), uma batalha estratégica entre negros do sul e seus opressores brancos sulistas pelo controle de recursos materiais (McAdams, 1982; Payne, 1995). Em meu trabalho, tenho proposto uma explicação alternativa. Certamente, o movimento por direitos civis quis remover as barreiras que impediam o acesso dos negros ao poder estatal. Mas, devido a uma complexa mistura de temores raciais e política democrática, a luta do movimento para conquistar esse poder não poderia ser violenta, sequer implicitamente coercitiva. O movimento só poderia recorrer à persuasão. Visando a influência, não o poder, produziu dramas simbólicos, projetando-os, não ao poder do estado sulista branco, mas para o público dos brancos do norte ${ }^{7}$.

Não era essa a direção declaradamente visada pelo movimento por direitos civis. Embora parecessem estar direcionadas às instituições do Sul, o verdadeiro público das mobilizações era de "terceiros" - cidadãos brancos que assistiam a esse confronto no Norte. Frente ao público imediato de brancos do sul, as campanhas por direitos civis mostravam-se fracas e, de fato, com frequência foram derrotadas. Alguns brancos sulistas tinham os olhos abertos, mas a grande maioria estava indiferente, ignorando.

Os públicos modernos são dispersos, estratificados, e fragmentados. Os performers não podem esperar se conectarem com todos ao mesmo tempo. Martin Luther King afirmou publicamente que as táticas não-violentas foram concebidas para persuadir os brancos do sul, apelando a seu espírito cristão e democrático. Contudo, como bem sabiam os que dirigiam o movimento, as táticas de King foram, na verdade, projetadas para produzir um efeito bem diferente. Certamente, as ideias de King sobre a

\footnotetext{
${ }^{7}$ Evidentemente, primeiro, tinha que EXISTIR um movimento. As performances de King precisaram realmente mobilizar massas negras no sul. Não só King - como diretor e astro-, mas todo um elenco da infantaria negra produziram as performances dramáticas que puderam ser projetadas para o público branco no Norte.
} 
não-violência vinham de seus estudos de outro mestre da arte do protesto civil, Mahatma Gandhi. Gandhi acreditava que as performances iterativas da Satyagraha -"insistência na verdade" - acabariam por abrandar os Corações imperiais e mudariam o modo de pensar dos britânicos. Mas, o que funcionou para a o império britânico tardio não alcançou êxito na América de Jim Crow. O racismo da maioria dos brancos do Sul, tanto da elite como da massa, estava por demais arraigado para que fossem sensíveis a uma Satyagraha afro-americana. Apesar de seu idealismo cristão, King tinha plena consciência disso. Ele havia crescido neste Sul, mas realizara seu doutorado na Nova Inglaterra. Era a Satyagraha dos brancos do norte que King tinha em mente (Garrow, 1957) ${ }^{8}$.

De Frederick Douglas a W.E.B. Dubois, os líderes dos protestos afro-americanos eram atores sociais que tinham abertura para o dramático e capacidade de comandar a cena pública. Embora com ideologias e ambições muitas vezes divergentes, todos esses líderes compartilhavam uma coisa - a mais importante. Eles tinham uma percepção intuitiva da consciência coletiva americana, tanto branca como negra. Eles captavam aquilo que, na terminologia de Saussure, se poderia chamar de langue americana, a linguagem cultural que definia o cenário para as paroles do movimento por direitos civis, os atos de fala com que os movimentos afro-americanos engajaram-se e protestaram contra seus mundos sociais opressivos, os roteiros estratégicos que transmitiram não só para seus pares negros, mas também para os brancos na sociedade.

\footnotetext{
${ }^{8}$ Evidentemente, alguns brancos do sul apoiaram o movimento negro (Sokol, 2006), a maior parte deles passivamente, embora uns poucos de forma ativa: clérigos (Campbell, 1997), rabinos (Bauman; Kalin, 2014), mulheres (Little, 2009; Moody, 2011; Murphy, 1997), estudantes (Michel, 2004), editores (Roberts; Klibanoff, 2007) e empresários (Robinson; Sullivan, 1991). Embora Chappell (1994, p. xvi) argumente que "o apoio moral dissimulado dos brancos locais" era "imensamente encorajador para os manifestantes negros", a questão é que esse apoio raramente se tornou evidente. Um punhado de sulistas brancos pode realmente ter atuado como "agitadores internos" (Chappell, 1994), mas esses eram invisíveis aos olhos do público. Os brancos do sul que experimentavam empatia e mostravam apoio não podiam ser incluídos publicamente na cena performativa. No drama nacional de direitos civis, o "papel" reservado ao branco sulista era o das figuras que representavam massas racistas e elites repressivas.
} 
As linguagens culturais arraigadas, compartilhadas por americanos negros e brancos, foram formadas por esforços seculares de pensamento republicano e liberal antiautoritário, juntamente com os temas religiosos do cristianismo profético. Os negros identificavam-se com os judeus do Egito faraônico, vendo seu próprio destino e perspectivas na história do Êxodo. Para os brancos, sua missão nacional remontava à rebelião contra o rei George III, e, no período pós-revolucionário, viam-se presos a uma batalha pela democracia frente à aristocracia europeia, ao império e ao despotismo. Durante os três primeiros séculos da experiência americana, no entanto, o racismo impediu os brancos de identificarem sua própria narrativa de emancipação com a luta dos negros pela liberdade. Só aos poucos, com o surgimento de performers afro-americanos persuasivos como Douglas, Tubman e Dubois, e de organizações de difusão como a NAACP (Organização Nacional para o Progresso das Pessoas Não Brancas), desenvolveu-se o potencial para tal identificação mútua.

Homem de elevada educação, profundamente religioso, de personalidade ousada, e dramaturgo excepcionalmente dotado, o Reverendo Martin Luther King definiu os brancos sulistas como o público alvo declarado dos protestos por direitos civis. Contudo, na prática, em suas cenas de protesto, King transformou os brancos sulistas em meros coadjuvantes. Ele os transformou, de inimigos reais, em imaginários, figuras míticas em uma peça de moralidade que ele idealizou, roteirizou e coreografou, e na qual ele próprio desempenhou o papel de ativista principal. Vezes sem conta, esses dramas do movimento subverteram os poderes brancos sulistas, provocando-os a desempenhar o papel antidemocrático de anti-Cristo em seus roteiros civil-religiosos.

Quando Rosa Parks recusou-se a mudar para a parte traseira do ônibus, em Montgomery, Alabama, em dezembro de 1955, seu ato corajoso parecia ser um protesto individual espontâneo. Na verdade, ele fora longa- 
mente planejado pela seção local da NAACP, cuja secretária era a própria Parks. O que não se poderia saber de antemão, contudo, era que a escolha para liderar a turbulência resultante recairia em um recém chegado ao ministério local, um jovem pregador chamado Martin Luther King.

Sustentar o boicote não-violento ao ônibus de Montgomery durante doze longos meses exigiu uma combinação favorável de uma ampla gama de performances. O sucesso do protesto dependia de uma equipe de produção afinada; ensaios minuciosos nos bastidores por parte dos atores civis; direção permanente dos dramas em desenvolvimento; roteiros suficientemente flexíveis para manter a trama dramática e a clareza moral através dos imprevisíveis altos e baixos; e recursos materiais suficientes para assegurar a milhares de pessoas entre a população negra, em condições financeiras difíceis, transporte privado, fiança para sair da prisão e representação legal (Branch, 1988). O drama social exigia também um protagonista heróico, capaz de apresentar-se impávido diante dos níveis de repressão da polícia-estadual e capaz de inspirar retoricamente uma fervorosa identificação emocional e inspiração moral (ver Meier, 1965).

King transmitiu não só localmente o roteiro de protesto, para as massas negras que serviram de elenco e coro ao movimento de Montgomery, mas também nacionalmente, para os cidadãos do norte, através de repórteres brancos fortemente impactados pelo tom sublime que King imprimia em sua pauta civil-religiosa: "Esse incidente do ônibus foi o fator detonador, mas há algo muito mais denso. Há uma profunda determinação [...] de sublevar-se contra essas forças opressivas" (cfe. Lentz, 1990, p. 26). Citando a retumbante declaração de King de que "uma das glórias da América" era "o direito de protestar por direitos", a Newsweek, uma revista semanal influente, retratou o protesto de Montgomery em termos civis, e não raciais ou econômicos. Após o sucesso do boicote, a revista Time colocou King em sua capa, descrevendo-o como "aquele que mui- 
tos negros - e, não fosse por sua cor, muitos brancos - gostariam de ser" (cfe. Lentz, 1990, p. 34) .

Montgomery foi o primeiro ato de uma série de eventos de protesto que intensificou continuamente a tensão do drama, um drama social com décadas de duração que idealizou a vitória do bem civil sobre o mal anti-civil. Ocorreram as tensas, vividamente relatadas, ocupações dos balcões de lancherias de 1960, em que um grande número de estudantes manifestantes não violentos foram detidos e encarcerados. Houve as terrivelmente arriscadas Freedom Rides (Viagens da Liberdade) em 1961, que defrontaram-se com hediondos espancamentos e foram exibidas nos noticiosos noturnos de televisão como corajosos atos de protesto contra a brutalidade criminosa.

Quando policiais brancos, com suas mangueiras de incêndio e cães ferozes atacaram adolescentes estudantes negros, em Birmingham, Alabama, no verão de 1964, transformou-se em um drama que capturou e indignou como nunca antes a visão cívica nortista (Eskew, 1997); e quando, um ano depois, a polícia do estado de Alabama atirou contra manifestantes não violentos determinados a atravessar uma ponte em Selma, o drama fez crescer a mais profunda crise moral, que se alastrou na consciência coletiva nortista (Garrow, 1978). Os líderes do movimento escolheram Birmingham e Selma, precisamente, porque sabiam que as lideranças brancas nessas cidades eram particularmente propensas a explosões racistas e manifestações antidemocráticas; e os eventos de protesto foram roteirizados, ensaiados, coreografados e engenhosamente controlados artisticamente no desenrolar dos atos. Contudo, como explicou Coleridge, o artifício do drama jamais pode se evidenciar: o efeito dramático depende da suspensão voluntária do ceticismo. Os brancos sulistas ignoraram os protestos por direitos civis, considerando-os incidentes fabricados, mas o público branco do norte os via como genuínos e profundamente francos, como expressões gritantes da realidade da opressão racial. 
À medida que os brancos nortistas testemunhavam esses desdobramentos do drama dos direitos civis, os quais, graças aos noticiários televisivos, pareciam ocorrer em tempo real, sua empatia pela "causa perdida" dos brancos sulistas desfez-se gradualmente. "Nós, jamais, [...] dispersamos nossos esforços", King confidenciou a um jornalista em 1964, "e sim focamos em objetivos simbólicos específicos" (Garrow, 1978, p. 321). O poder simbólico, King sabia, tem efeitos reais. Enternecidos com os protagonistas negros, e não com seus oponentes sulistas brancos, os cidadãos e cidadãs do norte exigiram que o poder federal fosse mobilizado para proteger a impotente população negra e punir seus opressores brancos. Em 1964 e 1965, o Congresso, atuando na esteira do assassinato de JFK, aboliu as leis de segregação e aprovou legislação que assegurava aos negros direitos civis e políticos. O poder dos estados do Norte invadiu os estados da antiga Confederação. Para muitos, isso constituiu a segunda Reconstrução.

\section{"Black Lives Matter" na América do século 21: uma nova questão negra}

O movimento por direitos civis dos anos 1950 e 1960 teve seu foco nos Estados Unidos, mas também inspirou o imaginário coletivo global, projetando cenas dramáticas, para além do âmbito local, a centenas de milhões [de pessoas] que tiveram contato com as performances no exterior. Ele deu início a uma narrativa em série, uma iteração sequencial da performance social utópica que, ao longo das décadas subsequentes, arraigou-se profundamente na cultura, não só nos Estados Unidos, mas também na sociedade civil global.

O ideal utópico da solidariedade cívica não se acomoda em um mundo de desigualdade social, estigma e repressão (Alexander, 2006). A insatisfação com as formas existentes de organização social é crônica, e a esfera 
civil está inquieta. Episódios de liminaridade e dramas sociais que exigem reparação cívica são o resultado periódico: o movimento Solidariedade, na Polônia; a Revolução do Poder Popular, nas Filipinas; as Revoluções de Veludo, na Europa Central e Oriental; Tiananmen; Obama; a Primavera Árabe; Ocupar; a Revolução dos Guarda-Chuvas, em Hong Kong. Alguns desses movimentos conseguiram tomar o poder estatal; todos geraram um poder simbólico extraordinário. Foram dramas políticos auspiciosos, desenrolados em praça pública, em suas próprias localidades e diante da audiência ampliada de "toda a humanidade" (Alexander, 2013) ${ }^{9}$.

Contudo, nesta seção final, estou interessado, não nessas ramificações globais, nem nas últimas décadas, mas em um novo movimento de direitos civis surgido recentemente no cenário americano, o movimento Black Lives Matter. As performances iterativas do movimento por direitos civis de meados do século vinte deixaram de herança uma cultura profundamente enraizada, um conjunto de experiências-modelo intensamente evocativas, que os protestos afro-americanos posteriores sentiram-se compelidos a tomar como base. Mas, como vimos ao longo deste ensaio, há uma enorme distância entre os modelos - estruturas culturais que fornecem a langue para a ação simbólica - e as atuações concretas, situadas

\footnotetext{
${ }^{9}$ As performances iterativas que constituíram a Revolução Chinesa, antes e depois da mudança para o regime comunista em 1949, criaram uma igualmente poderosa narrativa seriada que reverberou pelas décadas seguintes, na cena global. Sem o roteiro maoísta, é difícil imaginar as correntes de anticolonialismo das décadas de 1950 (por exemplo, Fanon e Castro) e de 1960 (Che Guevara) que promoveram violenta revolução agrária e, com frequência, violência exemplar como um gatilho precursor (Alexander, no prelo), e muito menos as performances revolucionárias de grupos de esquerda ocidentais como os Weathermen e os Black Panthers, que definiram seus roteiros recorrendo às performances de Mao, Fanon e Che. No entanto, o maoísmo e suas iterações eram revolucionários, não movimentos da sociedade civil. Em contrapartida, o movimento por direitos civis dos EUA estava orientado para uma reforma radical, não para uma revolução, e sua adoção da não violência foi fundamental para essa performance. Esse foi o diferencial que lhe permitiu tornar-se uma inspiração central, um guia transformador para os movimentos radicais da sociedade civil que surgiram na esteira do desmoronamento da utopia socialista.
} 
no tempo e no espaço, que são informadas por essas estruturas. As atuações são como atos de fala pragmáticos, não emanações de estruturas culturais, e exigem que cada um dos outros elementos da performance seja posto em ação.

Entre a tradição de protesto afro-americana concretizada em meados do século vinte e as condições da população negra pobre das periferias das cidades do início do século 21, emerge o imenso desafio de forjar novos roteiros orientados à ação. Tais roteiros precisariam ainda ser postos em ação, de modo a informar cenas dramáticas, capazes de atrair, motivar e, mesmo congregar grupos sociais fragmentados segundo fatores raciais e de classe, e desmotivados pelo fatalismo político. Seria preciso, também, haver lideranças fortes, com talento dramatúrgico capaz de produzir performances de protesto, e de direção para dirigir as performances. A fusão exitosa de público, roteiro e atores exigiria, ademais, o acesso aos meios de produção simbólica; interpretação empática das atuações em curso, por parte dos críticos, tais como jornalistas e intelectuais; e suficiente influência ante os poderes relevantes para evitar repressão pelas forças do Estado.

Esses diversos elementos foram, de fato, postos em prática pelo movimento negro pelo fim da violência policial, que vem ganhando impulso desde $2012^{10}$. Foi necessária uma criatividade extraordinária para engendrar cada ato performativo. Juntar esses últimos na sequência iterativa que possibilitou aos afro-americanos, uma vez mais, ocupar a cena política da nação exigiu habilidade, determinação e sorte.

A subclasse torna-se atuante

Passaram-se décadas desde que os afro-americanos conseguiram fazer isso. A vitória do movimento por direitos civis de meados do século

\footnotetext{
${ }^{10}$ Sou grato a Anne-Marie Champagne pela assistência de pesquisa aportada por ela nesta seção.
} 
vinte foi decisiva, mas parcial. Os portões do gueto (Duneier, 2016) se haviam destrancado para operários, técnicos, profissionais e empresários afro-americanos (Landry, 1988). Tais grupos, é verdade, permaneceram submetidos a um estigma racial generalizado (Anderson, 2012; 2015), mas sua liberdade de movimento expandiu-se muito. Contudo, quando esses deixaram o gueto, os sem escolaridade, os não qualificados e os desempregados foram deixados para trás, na perifieria da cidade, e formaram uma subclasse racial, em condições muitas vezes desesperadoras e sempre degradantes, mescla de uma classe dominada e do resquício de uma raça ainda desprezada (Wilson, 1987). Preconceitos racial e de classe erigiram uma barreira cultural em torno desse grupo periférico (Patterson, 1998); políticos, incorporadoras imobiliárias, tribunais, polícias e prisões impuseram-Ihes controles de natureza administrativa, coercitiva e material (Massey; Denton, 1993). Jovens negros, principalmente, foram encarcerados, em índices alarmantes, muitas vezes por atos que não resultariam em prisão, se os perpetradores fossem brancos.

Afro-americanos trabalhadores e de classe média povoaram o movimento por direitos civis do século vinte, provendo um capital cultural decisivo. Eles aportaram educação e talentos profissionais para as ações de protesto, e a igreja negra, com seus fortes vínculos e alcance institucionais (Putnam, 2000), proporcionou não só confiança generalizada, como também espaços protegidos, nos quais as performances públicas podiam ser ensaiadas (Morris, 1984). Como tais recursos dificilmente estariam disponíveis para a nova subclasse racial, sua capacidade de agência política ficou severamente reduzida.

No entanto, em princípio, se não na prática, a capacidade de mobilizar protesto social em favor da subclasse seguiu existindo, juntamente com a possibilidade de inspirar a crítica social generalizada pela reparação cívica por parte das instituições que sustentaram sua devastação. Apesar 
das fissuras, contradições, do liberalismo frouxo e da reação conservadora, a esfera civil nos Estados Unidos segue sendo potencialmente capacitadora, com seus ideais e instituições de prontidão, caso se possam efeuar os arranjos sociais apropriados. Produzir tais arranjos exige um movimento social com grande capacidade performativa, capaz de dramatizar o sofrimento de subclasse de forma tal, que novas redes de significado possam se formar entre grupos raciais marginalizados, excluídos da esfera civil, e os grupos centrais que ocupam posições estáveis e influentes dentro dela.

A partir de 2012, um tal movimento, fortemente performativo, pelos direitos civis dos negros começou a tomar forma. Os disparos de policiais contra homens negros têm sido rotina há décadas, mas só raramente ganharam visibilidade pública. Isso mudou quando mobilizadoras ${ }^{11}$, apoiadas nas tecnologias de internet, criaram slogans sucintos e sugestivos, e símbolos visuais, disseminando-os nas redes sociais. Quando seus celulares e computadores acenderam, dezenas de milhares de corpos negros${ }^{12}$ tomaram as ruas, em manifestações coreografadas que sugestivamente contrastavam a inocência negra com a brutalidade policial. Antes uma rotina, os disparos da polícia transformam-se agora em drama atroz, de incontestável abuso de autoridade. Kuttner o coloca com perfeição:

Nem a violência policial nas comunidades negras nem a resistência a essa violência são novas. Mas algo novo surgiu: um novo foco de ira e desespero, uma fonte essencial de esperança, um novo catalisador do imaginário social e da criatividade. Sem dúvida, há muitas razões para o surgimen-

\footnotetext{
${ }^{11}$ [NT] O movimento Black Lives Matter foi iniciado por Alicia Graza, Opal Tometi e Patrisse Cullors, três mulheres negras que, indignadas com o desfecho do assassinato de Trayvon Martin, adolescente negro de 17 anos, por George Zimmerman, que acabou absolvido do crime. (Black Lives Matter website. Herstory. http://blacklivesmatter.com/herstory/).

${ }^{12}$ [NT] No original, black bodies. O autor utiliza um termo que difundiu-se entre cientistas sociais nos Estados Unidos, como tentativa de evidenciar o tratamento das pessoas negras como objetos, não como indivíduos. O termo, no entanto, não está livre de críticas, uma vez que tende justamente a reproduzir a objetificação que pretende evidenciar.
} 
to de um movimento, neste momento particular. [Um] fator foi, certamente, a habilidade com que os organizadores empregaram símbolos, hashtags, cantos, metáforas e imagens para comunicar - de forma rápida e impactante - os valores subjacentes ao movimento e seus objetivos. Todo movimento social desenvolve uma provisão de símbolos. Esses símbolos dão coerência aos dispersos esforços das bases. Eles valem-se de nossas emoções e incentivam-nos a aprender mais. Fazemos uso deles para marcar nossa identidade coletiva e captar o interesse dos meios de comunicação, com seus conhecidos breves períodos de atenção. (Kuttner, 2015, destaque no original)

Segundo o Huffington Post, o movimento Black Lives Matter "reformulou o modo como os americanos veem o tratamento policial dado às pessoas não brancas" (McLaughlin, 2016). As vidas das pessoas negras pobres começaram a ter importância.

O Movimento conseguiu ativar um sentimento de alerta vermelho em torno de um problema crônico que, até agora, permanecera praticamente invisível fora das comunidades que sofrem com isso. [...] Não há evidências de que os disparos contra homens negros por agentes de polícia tenham aumentado significativamente. No entanto, os assassinatos perpretados por policiais ganharam a primeira página dos jornais e viraram ponto de ignição político, exclusivamente por conta do sentido de emergência que o movimento tem sustentado. (McLaughlin, 2016)

O New York Times descreve de modo semelhante o efeito dramático dos protestos: "A rapidez com que atua o movimento e o número de pessoas que consegue mobilizar a cada protesto transformaram cada assassinato praticado pela polícia em um referendo nacional sobre o valor das vidas das pessoas negras na América" (Kang, 2015).

O impacto desses referendos simbólicos tem sido o de ampliar a empatia e a identificação com a classe marginalizada. Até recentemente, segundo Pew (2015), “a opinião pública estava [...] muito dividida” em 
relação à necessidade ou não de mudanças significativas para alcançar a igualdade racial. Em julho de 2015, após três anos de mobilização social, para cada americano satisfeito com o status quo havia dois que acreditavam serem necessárias mudanças profundas: "Essa mudança na opinião pública está em toda parte. Parcelas cada vez maiores da população, em todas as regiões do país, e em todos os grupos demográficos e partidários, afirmam que o racismo é um problema sério e que é preciso fazer mais para alcançar a igualdade racial" (Pew, 2015).

Expor a indignação e expandir a empatia

De que modo essas performances de protesto, principalmente negras, lograram influenciar a ainda majoritáira população branca americana? Ao se desenrolar nas telas de TV e de computadores, a onda de manifestações sem precedentes contra a brutalidade policial parecia espontânea, como se emergisse das bases, brotando da própria classe marginalizada e vitimada. No entanto, não foi esse o caso. Certamente, as manifestações eram sinceras. Seu realismo, contudo, foi coreografado, sua verossimilhança resultava de uma fusão singular entre atores e público, realçada pelo efeito performativo.

Com o assassinato do estudante secundário, Trayvon Martin, de 17 anos, por George Zimmerman, coordenador da vigilânciade um condomínio fechado em Sanford, Florida, em 26 de fevereiro de 2012, a comunidade negra nacional e seus simpatizantes brancos monopolizaram as ondas de rádio com sua indignação contra o racismo e a irresponsabilidade civil. Quando o chefe da polícia local se recusou a prender Zimmerman, alegando que a lei de Stand Your Ground ${ }^{13}$ da Flórida permitia a ele

\footnotetext{
${ }^{13}$ [NT] Stand your Ground é uma legislação inusual de legítima defesa, que vigora em alguns estados americanos, e serve como justificativa em processos criminais. A lei assegura o uso da força e de armas, caso uma pessoa esteja de fato, ou simplesmente perceba-se, ameaçada, sem que precise tentar fugir ou proteger-se da ameaça. Ou seja, pode atacar quem supostamente oferece ameaça, usando armas, e alegar legítima defesa.
} 
exercer sua autodefesa armada, milhares protestaram, e suas manifestações surpreenderam e fascinaram aquela que acabou sendo uma nação amplamente solidária aos protestos. A reação foi tão eletrizante quanto inesperada, distendendo, como nunca antes, os limites da ética interracial e da empatia afetiva.

Quando o Presidente Obama consolidou publicamente essa empatia, afirmando em tom dramático: "Quando penso nesse menino, penso nos meus próprios filhos [...] Se eu tivesse um filho, ele se pareceria com Trayvon" (Shear, 2012), falava não só em seu nome e no de outros pais e mães afro-americanos, mas por uma parcela muito maior de cidadãos e cidadãs que ele representava como Presidente dos Estados Unidos. O grupo de protesto Million Hoodies for Justice, formado um mês após a morte de Trayvon, organizou uma marcha em Nova York na qual os manifestantes repetiam em coro: "Queremos prisões!" e "Todos somos Trayvon", muitos vestidos de blusões com capuz, "símbolo do que vestia Martin quando foi morto" (Miller, 2012). Duas semanas depois, Zimmerman foi acusado de assassinato por um promotor especial nomeado pelo Governador Rick Scott, um republicano conservador.

Quinze meses depois, com a absolvição de Zimmerman, a indignação social mais uma vez se acendeu, explodindo, então, com a notícia de que Eric Garner, um afro-americano pai de seis filhos, havia morrido, quando um agente branco da polícia de Nova York o submeteu por 20 segundos a uma gravata mortal, ao efetuar sua prisão. Os protestos, que se multiplicaram por dias e semanas por várias cidades dos EUA, encenaram pessoas mortas; manifestantes deitavam-se no meio de ruas movimentadas e gritavam as últimas palavras de Garner: I can't breathe! (Não consigo respirar!). Quando, em 9 de agosto de 2014, apenas um mês após a morte de Garner, um policial branco em Ferguson, Missouri, atirou em outro jovem negro, Michael Brown, mais uma vez, explodiram protes- 
tos. As últimas palavras de Brown foram: I don't have a gun, stop shooting! ("Eu não tenho arma, parem de atirar!").Essas preces seculares, de pleito e protesto"tornaram-se grito nacional de mobilização", segundo o New York Times (Healy et al., 2015). Ao entoar essas palavras em cidades e campi por todo o país, manifestantes também exibiam gestos evocativos, reconhecidos de imediato como recriação ritual. Erguer os braços acima da cabeça, por exemplo, em solidariedade a Michael Brown, o adolescente negro que, segundo testemunhas, se rendia quando foi baleado.

Em dezembro de 2014, quando um grande júri se recusou a indiciar responsáveis pela morte de Eric Garner, os protestos urbanos ganharam um toque febril. Colocadas em cena com ira e determinação por afro-americanos que confrontavam o risco da repressão policial, palavras dramáticas e movimentos coreografados foram transmitidos ao vivo pelas redes sociais e, sendo reportados nas grandes redes de notícias, ricochetearam por todo o país. Cantando e erguendo os braços em gestos arquetípicos de solidariedade e medo, os manifestantes desfilaram em praças públicas, bloquearam estradas locais e interestaduais, estorvaram centros comerciais, feriados religiosos e eventos políticos. Seus slogans e gestos transformaram-se em totens - "Mike Brown é um emblema", declarou um manifestante na Filadélfia (Associated Press, 2014) - e foram disseminados por ícones afro-americanos, celebridades dos mundos da música, do cinema, dos esportes, do teatro e da política. Defronte à delegacia de polícia da Broadway, em New York, atores afro-americanos protestaram dançando e cantando um rap sincronizado. Durante um jogo de basquete entre Cleveland Cavaliers e Brooklyn Nets, fora do estádio, milhares de pessoas circulavam protestando, enquanto, no interior, o superstar LeBron James vestia uma camiseta com os dizeres I Can't Breathe, proclamando aos meios de comunicação nacionais: "como sociedade, precisamos melhorar [...] ser melhores um para o outro, independentemente de sua raça" (Zillgit; Strauss, 2014). 
Jarret Jack, armador do Brooklyn Nets, explicou: "Não estamos voltados só para nós mesmos como atletas [...] Entendemos, como grupo, que esta é uma questão que precisa ser abordada. Quanto mais atenção e consciência pudermos trazer para ela, melhor. Não é uma questão de cor da pele, é de gente. É uma questão de cidadania" (Zillgit; Strauss, 2014). Os manifestantes fora da arena do Cleveland aplaudiram essas atitudes, percebendo seu potencial de conectar-se com um público ainda mais amplo. "Isso é porque eles são camaradas educados e têm um mínimo de consciência ética", afirmou um manifestante identificado apenas como L.B., "eles sabem que estão sob os holofotes. Qualquer pessoa que tenha algum tipo de visibilidade pública deve se manifestar e fazer alguma coisa"(ibid.).

Transmitir as atitudes e vozes de tais celebridades teve impacto. Os atos simbólicos ritualizados produziram uma efervescência coletiva que reverberou em grandes ondas e foi registrada por analistas políticos que detectavam a mudança de opinião. Donna Brazile, influente analista política afro-americana e estrategista do Partido Democrata, declarou:

Hands Up, Don't Shoot! transformou-se no grande símbolo do desejo de provar a inocência de alguém [...] Isso vai ressoar sempre, de diversas formas, como um símbolo de um adolescente desarmado estirado morto na rua por muitas horas. Assim como "I can't breathe!" não vai mais desaparecer. São gritos gravados para sempre na complicada história do viés racial de nosso sistema de justiça criminal. (Healy et al., 2015) 


\section{Black Lives Matter toma o palco}

Foi em meio aos protestos em Ferguson que Black Lives Matter - o hashtag, a organização e o amplo movimento epônimos - surgiu na cena pública ${ }^{14}$. \#BlackLivesMatter foi criado no dia em que libertaram George Zimmerman, mas raramente evocado, ao longo do ano que se seguiu. Depois do assassinato de Michael Brown, o \#BLM liderou as Freedom Rides que alimentaram a conflagração em Ferguson, e o número de visitantes do seu site disparou cem vezes (Freelon et al., 2016). Um informe entusiástico publicado então no site ativista de língua espanhola, teleSUR, é revelador: "Uma coalizão nacional determinada a desafiar a violência estatal se reunirá em Ferguson nos próximos três dias", informou o TeleSUR, descrevendo os objetivos da reunião em termos performativos: "recriar uma plataforma política negra nos Estados Unidos". O grupo que iria construir esta plataforma era o Black Lives Matter. TeleSUR ligou a organização à tradição consagrada dos direitos civis afroamericanos, propiciando a uma das fundadoras da organização uma plataforma para falar publicamente sobre repressão, resiliência e destino.

Na sexta-feira, cerca de 600 pessoas se reunirão em Ferguson, Missouri, vindas de todas as regiões dos Estados Unidos, participando da jornada Black Life Matters Ride (BLM). "A Black Life Matters Ride é a Freedom Ride da nossa geração", explica a co-organizadora do movimento, Patrisse Cullors. [...] A BLM Ride nasce do espírito e da história das Freedom Rides para o Mississippi, nos anos 1960, que visavam acabar com a segregação racial". [...] A BLM Ride é uma

\footnotetext{
14 “Há, evidentemente, uma certa sobreposição entre \#Blacklivesmatter e Black Lives Matter: os membros da organização (e muitas outras pessoas) usam a hashtag, o que, por sua vez, provavelmente leva potenciais membros para a organização. Ao mesmo tempo, os dois termos são usados, às vezes, com referência a uma terceira ideia: o conjunto de todas as organizações, indivíduos, protestos e espaços digitais dedicados a promover a conscientização e pôr fim à brutalidade policial contra afroamericanos" (Freelon et al.; 2016, p. 9).
} 
chamada à ação para que as pessoas negras de todo o país se reúnam para rearticular nosso destino", ressalta Cullors. [...]"Acreditamos que, para tirar este país de um ciclo de destruição e trauma, temos que nos levantar, tanto local como nacionalmente. Ferguson representa tanto a repressão que prevalece nas comunidades negras como também nossa imensa resiliência" [...], defende a BLM em seu National Advocacy and Organizing Toolkit (TeleSUR, 2014).

Graduada em Religião e Filosofia pela UCLA, Patrisse Cullors foi Coordenadora do Centro Ella Baker de Direitos Humanos, de Oakland, uma organização sem fins lucrativos voltada à promoção da justiça social nas regiões periféricas da cidade (Cobb, 2016, p. 36). Cullors criou o hashtag \#BlackLivesMatter a partir de uma postagem de sua amiga Alicia Garza, no Facebook, no dia da absolvição de George Zimmerman. "O mais triste de tudo isso", escreveu Garza, "é que há uma parte da América que hoje está aplaudindo e comemorando. E isso me revolta o estômago. TEMOS QUE estar todos juntos nisso". Garza acrescentou, mais tarde:

Aliás, vamos parar de dizer que não estamos surpresos. Isso é deplorável. Ainda me espanto com o pouco valor atribuído às vidas das pessoas negras. E seguirei me espantando. Não deixe ao léu as vidas das pessoas negras [...]. Amo vocês. Amo nós todas e todos. Nossas vidas importam. (Cobb, 2016, p. 35)

Garza estudou antropologia e sociologia na Universidade da Califórnia, em San Diego, e trabalhou como diretora de projetos especiais na sede de Oakland da National Domestic Workers Alliance, que representa vinte mil cuidadores e empregados domésticos. A terceira fundadora da BLM é Opal Tometi, escritora e coordenadora de direitos de imigração no Brooklyn, e foi quem construiu uma rede social no Facebook e no Twitter para que, nas palavras do jornalista Jelani Cobb, os ativistas pudessem utilizar a hashtag para "conectarem-se entre si" (Cobb, 2016, p. 26). Como 
disse Cobb, as três mulheres "começaram a pensar em transformar a frase em um movimento" (ibid).

Organizadoras, produtoras, diretoras, e ativistas

Garza, Cullors, e Tometi tornaram-se dramaturgas invisíveis, redigindo os roteiros para as performances de ampla visibilidade de sua organização. Elas não estavam em cena, mas nos bastidores. Rememorando, Cullors atribuiu-se o papel de produtora e diretora, diferenciando essas responsabilidades daquelas de participar das performances em tempo real e gerenciar a atuação.

Eu me identifico como organizadora em contraposição a uma ativista, porque acredito que a organizadora é a menor unidade em torno da qual você constrói sua equipe. A organizadora é a pessoa que reúne a imprensa e que forma novas lideranças, a pessoa que ajuda a construir e lançar campanhas, e é a pessoa que escolhe quais serão os objetivos e como vamos mudar esse mundo. (http://patrissecullors.com/bio/)

Foi alguém de fora do grupo fundador de organizadoras invisíveis, um ativista do Brooklyn, amigo de Cullors, Daniel Moore, que efetivamente coordenou as "viagens da liberdade" para o Missouri, saindo de Nova York, Chicago, Portland, Los Angeles, Filadélfia e Boston. Logo, Moore ganhou o apoio de DeRay Mckesson, um administrador escolar de Minneapolis, de 28 anos, que, impressionado com as imagens e textos que surgiam em seu feed no Twitter, dirigiu por mil quilômetros até Ferguson para lançar-se ao ato de protesto (Kang, 2015). Em Ferguson, durante uma simulação externa em um curso de primeiros socorros, Mckesson encontrou Johnetta Elzie, 25 anos, nativa de St. Louis, que cursara jornalismo. Os dois tornaram-se parceiros mobilizadores e organizadores das ações de rua, compartilhando avidamente informações e presentes em praticamente todos os eventos nas semanas e meses seguintes. 
Os registros de Elzie estavam entre as mais confiáveis observações em tempo real dos confrontos entre manifestantes e polícia. Ela fotografou os organizadores dos protestos, os sanduíches que preparava com seus amigos para alimentar outros manifestantes, os monges budistas que apareceram no posto QuickTrip incendiado" ${ }^{15}$. Mckesson, também, "tuitava" em tempo real, integrando vídeos e referindo-se tanto a manifestantes como a policiais pelo nome. Os tweets de McKesson eram geralmente sóbrios e detalhados, enquanto os de Elzie eram joviais e sarcásticos. (Kang, 2015)

Em pouco tempo, Elzie e Mckesson tornaram-se "as figuras mais conhecidas no movimento em Ferguson" (Cobb, 2016, p. 36). À medida que se replicavam os protestos afro-americanos em resposta a novos disparos pela polícia, ambos ganharam visibilidade pública, destacando-se na emergente, embora ainda quase anônima, "questão negra", cujo poder de congregação se fazia ver e ouvir cada vez mais nas telas de televisão e de computadores.

Mckesson e Elzie logo passaram a aparecer regularmente na $T V$ e no rádio. Ambos cultivavam uma imagem pública cativante, tornando-se facilmente reconhecíveis para seus muitos seguidores. Mckesson começou calçando tênis vermelhos e camisa vermelha para os protestos. Mais tarde, substituiu este traje por um colete Patagônia azul claro, que agora usa em todos os lugares aonde vai. (Alguém criou uma conta do Twitter do colete de DeRay). Elzie geralmente usava batom escuro, óculos de sol e uma jaqueta de couro: a filha da esteticista encarnando uma Black Panther. (Kang 2015)

Esta passagem é de uma matéria sobre Mckesson e Elzie, publicada em uma edição de 2015 da New York Times Magazine - uma matéria longa, repleta de fotos coloridas e marcada por um tom entusiástico, até adulató-

\footnotetext{
${ }^{15}$ [NT] O posto e loja de conveniência Quick Trip, em Ferguson, Missouri, foi saqueado e incendiado, em 11 de agosto de 2014, como resultado da onda de ódio e indignação que explodiu após o homicídio de Michael Brown, dois dias antes, depois de Brown ter supostamente furtado um pacote de cigarros no Ferguson Market \& Liquor.
} 
rio, poder-se-ia dizer (Kang, 2015). Mckesson, posteriormente, lançou-se candidato a prefeito de Baltimore. Pouco depois, usando seus característicos tênis vermelhos e colete azul, apareceu como convidado no The Late Show, com Steven Colbert, e The Daily Show, com Trevor Noah.

O duplo movimento

Quando jornalistas e cientistas sociais começaram a examinar o novo movimento contestatório BLM, destacaram sua conectividade online, como se a expertise em software somada à ira e à determinação fossem, por si sós, suficientes para ativar as ondas de choque que reverberaram por todo um segmento social. Cativadas pela tecnologia, tais perspectivas truncam o processo performativo, ignorando o abismo que separa, de um lado, roteiros e atores, e de outro, o público - em outras palavras, tornam invisível o desligamento (de-fusion) entre os elementos performativos, o qual acentua as dificuldades culturais e pragmáticas para o êxito dramático.

O fato de existir essa tão desafiadora lacuna explica por que o movimento de protesto BLM constituiu-se como uma série de chamamentos e respostas inter-relacionados, mas separados - não uma performance, mas várias, independentes umas das outras temporalmente, espacialmente e demograficamente, embora vinculadas a um mesmo tema. As postagens mobilizadoras de líderes anônimas, como Garza e Cullors, foram reproduzidas por ativistas, como Mckesson e Elzie, e "re-tuitadas" para uma rede de centenas de organizadores que eram tidos como "posicionados" e "prontos para trazerem milhares de pessoas às ruas com um tweet" (Kang, 2015). Esses primeiros mobilizados dentre um público escalonado (Rauer, 2006) estavam preparados e comprometidos, aguardando ser "re-integrados" (re-fused). Mckesson colocou assim: "Quando eu 'tuíto' estou, basicamente, pregando aos convertidos" (Kang, 2015). Ele estava 
seguro de que o receptores de suas mensagens se tornariam atores nos protestos de rua. No entanto, de uma coisa este ativista não tinha tanta certeza - os impactos que essas coreografias produziriam sobre o público de uma camada mais afastada, aquele que assistia e ouvia notícias sobre as atuações de rua através da grande mídia. Mckesson esperava, é claro, que esse público mais distante se identificasse com os dramas que ele estava organizando, mas confessou que, nessa segunda fase, estava de fato remando contra a corrente.

O coração do movimento está [...] fechando ruas, fechando Walmarts, fechando qualquer lugar onde as pessoas se sintam confortáveis. Queremos que as pessoas se sintam tão desconfortáveis quanto nos sentimos quando ouvimos sobre Mike, sobre Eric Garner, sobre Tamir Rice. Queremos que eles vivenciem o que vivemos diariamente. (Kang, 2015)

Os protestos de rua do BLM não pretenderam tomar o poder; a maior parte deles sequer tinha demandas concretas. Sua ambição era, antes, comunicativa, consistia em criar performances dramáticas que provocassem empatia pelo sofrimento de outros da subclasse, gerando uma catexia emocional que ampliaria a identificação cultural, colocando "pessoas comuns" (brancos, principalmente) na posição de oprimidos, fazendo-as "vivenciar o que vivemos diariamente".

Para produzir tal experiência simbólica indireta, a descrição dos protestos nos noticiários foi fundamental. Esse é o segundo ato da performance do Black Lives Matter. Começa com jornalistas interpretando os protestos e produzindo narrativas que suas agências de notícias transmitem por via impressa, televisiva e de internet. O primeiro circuito do duplo movimento - orientações através das redes sociais para uma coletividade comprometida que conduziu corpos negros às ruas - produziu a performance da subclasse racial como uma nova questão negra. O segundo circuito performativo visou religar este protesto com um público muito 
mais distante. A nova questão negra tinha de ser reconhecida por grupos brancos influentes, e de modo empático.

Em sua extensa análise de 40,8 milhões de tweets relacionados ao movimento, entre 1o de junho de 2014 e 31 de maio de 2015, Freelon et al. (2016) reconstroem a estrutura de rede das comunicações digitais do BLM. Dois achados sugerem precisamente o tipo de duplo movimento que proponho aqui. O primeiro é de que a rede digital era frouxa, composta de laços tênues, entre os quais se observavam relativamente poucas trocas com retorno. Em lugar de uma "rede densa com muitos laços recíprocos"- propícia à construção de confiança entre os pontos de conexão - do tipo que, segundo Freelon e colegas, seria ideal para a "troca de ideias de como mobilizar" - os pesquisadores descobriram uma rede "extremamente difusa, evidentemente propícia à ampla distribuição e circulação da informação" (ibid., 16) ${ }^{16}$. O segundo achado refere-se não à geografia da rede, mas à identidade substantiva de seus nós. Os núcleos mais frequentemente conectados foram, de longe, veículos de mídia, não indivíduos ou grupos de protesto, e a maioria desses veículos era da mídia dominante ${ }^{17}$. "No caso da rede Black Lives Matter Web", concluíram Freelon e colaboradores, "o que se produz e distribui, prioritariamente, é a notícia, visando sua ampla disseminação" (ibid.).

\footnotetext{
16 “Com uma densidade gráfica de 0,003 ... apenas uma pequena fração de todos os links que poderiam existir dentro da rede realmente existe. A título de comparação, uma rede aleatória com o mesmo número de nós tem uma densidade de 0,02 , significando que a rede contém dois por cento de todos os laços possíveis. Há pouca reciprocidade entre os sites (em 97\% dos casos, os sites que se conectam com outro site não são conectados por este último). Poucos sites mostram múltiplos links para qualquer outro site, sejam esses unidirecionais ou recíprocos (o peso médio dos vínculos - o número de vezes que dois sites conectam-se entre si - é um, e apenas 30\% dos laços têm um peso maior que um)" (Freelon et al., 2016, p. 16).

17 "59\% de toda a rede Black Lives Matter são sites de notícias [e] mais de 75\% dossites com conexões diretas com BlackLivesMatter.com são sites de notícias. Nós identificamos que a rede, como um todo, é muito esparsa. No entanto, as conexões entre sites de notícias na rede são extremamente densas, o que significa que elels conectam-se principalmente entre si e muito menos com sites que não são de notícias" (Freelon et al., 2016, p. 17).
} 
Esses dados empíricos ilustram as estruturas neurais do duplo movimento. Os alertas dos organizadores dos protestos dispararam não só as performances nas ruas, mas também o reenvio massivo dos tweets entre ativistas que, em seguida, os postavam diretamente ou encaminhavams a jornalistas interessados. Uma vez alertados, os repórteres colocavam-se de imediato em cena, de modo virtual, em tempo real, ou presencialmente, no espaço real. Dando início ao segundo circuito performativo, os repórteres postavam relatos concomitantes aos eventos em seus blogs. Tais relatos eram captados pelos participantes das manifestações e, de forma quase simultânea, pelas dezenas, às vezes, centenas de milhares de expectadores externos, potencialmente atentos, muitos dos quais, por sua vez, os re(re)tuitavam para outros nós na rede.

Essa dupla estrutura performativa continuou operando mesmo com a mudança da organização e das táticas do movimento. No final de 2015, as polêmicas relativas às mortes perpetradas pela polícia pareciam estar arrefecendo $^{18}$. "Se o objetivo do Black Lives Matter era [...] convencer mais americanos da existência da violência policial", afirmou o New York Times, "então teve êxito". "Com essa conquista", observou a Time, "o ímpeto começou a mudar e a transformar-se em outra coisa, e reduziu-se o número de protestos" (Howard, 2016). A organização nacional do BLM fragmentou-se em mais de 30 grupos ativistas locais relativamente independentes. Embora continuassem a ocorrer manifestações dispersas, a atenção voltou-se para distúrbios mais focados (Aron, 2015; Ruffin, s/d; Stockman, 2016), especialmente campanhas políticas com visibilidade nacional (cf. Eligon, 2016). Manifestantes do \#BLM assumiram o con-

\footnotetext{
${ }^{18}$ No entanto, não as mortes em mãos da polícia. Em uma investigação que durou 12 meses e foi vencedora do Prêmio Pulitzer, o Washington Post apurou um total de 990 disparos fatais por agentes da polícia em 2015 (Kindy et al., 2015), e 250 nos primeiros 3 meses de 2016 (Sullivan et al., 2016). Entre os que foram mortos em 2015, as minorias estiveram desproporcionalmente representadas, sendo 258 afroamericanos e 172 hispânicos, totalizando 430, em comparação com 494 brancos. Um terço das vítimas tinha entre 18 e 29 anos.
} 
trole de um encontro da Netroots Nation, em Phoenix, que apresentava [Bernie] Sanders e Martin O'Malley, e começaram a gritar slogans (Helsel, 2015). Em um comício de Sanders, em Seattle, duas ativistas do \#BLM tomaram o microfone, exigindo que o candidato estendesse suas demandas por reformas radicais com enfoque em classe social para um enfoque também racial. Em Atlanta, o \#BLM interrompeu um discurso de Hilary Clinton sobre justiça criminal e raça. Em um comício na Filadélfia, seu marido, o ex-presidente Bill Clinton, tentou enfrentar as vaias de ativistas irados que associavam sua legislação criminal de 1994 com o encarceramento massivo de homens negros. "Os ativistas negros estão literalmente roubando a cena dos candidatos para 2016 - e está funcionando", afirmava o cabeçalho de um blog liberal (Moore, 2015a).

Ao que parecia, os que disputavam a candidatura democrata haviam "recalibrado suas mensagens e tom", certamente, em resposta aos ruidosos confrontos (Moore, 2015b). O'Malley desculpou-se por falar "todas as vidas são importantes" (ibid.). Sanders acrescentou "justiça racial" e reforma penal ao seu rol de prioridades políticas (ibid.). Hillary Clinton iniciou uma campanha chamada "Mães do Movimento", encorajando as mães de Trayvon Martin, Eric Garner, Michael Brown, Tamir Rice e Sandra Bland a "organizarem-se e correrem o país, junto com sua campanha", pagando suas despesas para que pudessem participar dos debates presidenciais democratas (Chozick, 2016a). Descrevendo o impacto dessa tática performativa, o New York Times observou o quanto ela reforçou a autenticidade da persona Hillary Clinton e a vitalidade e verossimilhança da performance de sua campanha:

ter essas mulheres ao seu lado proporcionou à Sra. Clinton testemunhos fortes e profundamente empáticos em seus apelos aos eleitores afro-americanos. E elas conferiram à sua campanha um desenvolvimento, muitas vezes, cauteloso e experimental, um tom franco, humano e, às vezes, angustiante. (Chozick 2016a) 
Bill Clinton também se sentiu compelido a responder publicamente - na manchete do New York Times: "Bill Clinton afirma lamentar seu confronto com manifestantes do Black Lives Matter" (Chozick 2016b).

As novas táticas turbulentas do BLM também estiveram direcionadas aos candidatos republicanos, mas, ao invés de buscar suscitar reações de apoio, esses protestos pareciam ter como objetivo destacar o que os ativistas consideravam a branquidade insensível do movimento conservador. A tática parecia particularmente eficaz frente à candidatura de Donald Trump. As respostas agressivas de seus partidários brancos às provocações do BLM intensificaram as preocupações, não só democratas, mas também republicanas em relação ao caráter antissocial, "que passa dos limites", assumido pela campanha do incorporador imobiliário de Nova York.

Embora o New York Times tenha descrito a sequência de manifestações iterativas analisada nesta seção como "o mais impressionante movimento de protesto americano do século 21, até o momento" (Kang, 2015), a capacidade performativa do BLM permaneceu relativamente restrita, comparativamente àquela produzida por seu predecessor de meados do século vinte. Para explicar a razão, é preciso mencionar elementos ausentes em sua performance social. Houve problemas, por exemplo, com o roteiro do BLM. O alcance persuasivo da indignação turbulenta é limitado. Um mito mais poderoso teria definido um caminho de redenção do sofrimento para a salvação, da subclasse para a justiça social, talvez ressaltando o "excepcionalismo americano" ou a ideia de que a América é o povo escolhido de Deus. O tom secular do BLM, no entanto, impediu qualquer vínculo com a religião civil americana (American civil religion) (Bellah, 1970).

A ausência de personagens míticos provou ser outro grande obstáculo. Os protagonistas precisam personificar-se para se tornarem heróicos; questões coletivas, discursos online e imagens digitais não são suficientes. 
DeRay Mckesson pode ter sido a única persona distinguível que emergiu de um movimento contestatório marcadamente anônimo, mas sua campanha para prefeito de Baltimore, em 2016, ainda patinou por falta de um "nome reconhecido" (New York Times, 2016). No final de dezembro de 2015, a CNN afirmou que Mckesson "comanda o diálogo" (Sidner; Simon, 2015). Quatro meses depois, a New York Times Magazine relatou que Mckesson "estava na lista dos maiores líderes mundiais da Fortune, no ano passado e que foi tantas vezes à Casa Branca, que diz não ficar mais nervoso" (Howard, 2016). Essas afirmações de poder carismático, no entanto, são um enorme exagero. Mckesson increveu-se no radar americano, mas não penetrou em seu núcleo sagrado. Ele não chegou a tornar-se uma representação coletiva do sofrimento e da esperança das pessoas negras, fosse para a subclasse racial ou para o público externo, multicultural e multiclasse, do drama de protesto. Mckesson não incorporava, em suas palavras, no tom de sua voz, ou nas linhas de seu rosto, as atuais aspirações afroamericanas por justiça. Organizador eficiente, que se tornou um rosto reconhecível, Mckesson foi antes uma celebridade, famoso por ser famoso, do que um herói genuíno ${ }^{19}$.

Os movimentos sociais não triunfam porque são materialmente fortes; eles tornam-se materialmente fortes, porque triunfam. Para explicar esse aparente paradoxo, tenho argumentado que os movimentos sociais devem ser entendidos como performances sociais. Para conquistar o poder no Estado, é preciso, primeiro, conquistar o imaginário coletivo, exibindo dramas no palco da vida social capazes de retratar o triunfo da

\footnotetext{
${ }^{19}$ É sugestivo o fato de que, ao relatar as muitas realizações de Mckesson, a Times tenha observado que "ele coleciona 'amizades' célebres (Azealia Banks, Jesse Williams, SusansWojcicki e Sarandon, Rashida Jones, Tracee Ellis Ross), [e] se refere a elas pelo primeiro nome", explicando que isso era "porque, durante o último ano e meio, ele foi o rosto mais conhecido do movimento Black Lives Matter, viajando por todo o país para protestar contra a violência policial" (Howard 2016).
} 
justiça, vinculando-se tão fortemente com públicos distantes, que uma grave insurreição se torna legítima.

O movimento comunista chinês afirmou ter surgido do choque de interesses objetivos, mas o próprio partido precisou fazer essas contradições de classe ganharem o tom de um drama de vida. Mao transformou-se em persona mítica, heróico salvador, e as massas camponesas tiveram que ser ensinadas a derramar lágrimas amargas. Apesar dos protestos de gerações de intelectuais críticos e reformadores jurídicos, os afro-americanos sofreram por décadas, praticamente em silêncio, após a escravidão. Foi o gênio performativo de Martin Luther King e de sua equipe de apoio que, finalmente, Ihes deram voz. O drama que eles esculpiram juntos projetou uma narrativa redentora que comprometeu o público nortista de brancos, alcançou significativo poder político e fez importantes reparos no roto traje racial da vida americana. Cinquenta anos depois, enquanto os cientistas sociais tratavam de definir as forças estruturais que confinam a nova subclasse negra, Black Lives Matter forjou uma questão negra atuante. Empregando novos meios digitais de produção simbólica, seus organizadores transmitiram narrativas, slogans e gestos persuasivos, provocando protestos massivos de afro-americanos e, através de vínculos com jornalistas simpatizantes, afirmando sua identidade racial e levando ao coração de uma nação que relutava em reagir a exigência de igual valor para as vidas negras que aquele atribuído às vidas brancas.

Jeffrey C. Alexander é Professor de Sociologia na Universidade de Yale, New Haven, CT, Estados Unidos. É Co-Diretor do Centro de Sociologia Cultural (Center for Cultural Sociology - CCS). $邓$ jeffrey.alexander@yale.edu 
Sociologias, Porto Alegre, ano 19, no 44, jan/abr 2017, p. 198-246

\section{Referências}

1. ALEXANDER, J.C. Cultural Pragmatics: Social Performance between Ritual and Strategy. Sociological Theory, v. 22, n. 4, pp. 527-573, 2004.

2. ALEXANDER, J.C. The Civil Sphere. New York: Oxford University Press, 2006.

3. ALEXANDER, J.C. The Performance of Politics: Obama's Victory and the Democratic Struggle for Power. New York: Oxford University Press, 2010.

4. ALEXANDER, J.C. Performative Revolution in Egypt: An Essay in Cultural Power. London: Bloomsbury, 2011a.

5. ALEXANDER, J.C. Performance and Power. Cambridge, UK: Polity Press, 2011b.

6. ALEXANDER, J.C.. 2013. The Arc of Civil Liberation: Obama-Tahrir-Occupy. Philosophy and Social Criticism, v. 39, n. 4-5, pp.341-347, 2013.

7. ALEXANDER, J.C. Dramatic Intellectuals: Elements of Performance. European Journal of Social Theory, no prelo.

8. ALEXANDER, J.C.; JAWORSKY, B. Obama Power. Cambridge, UK: Polity Press, 2014.

9. ALEXANDER, J.C.; SMITH, P. (eds.) The Cambridge Companion to Durkheim. New York: Cambridge University Press, 2005.

10. ALEXANDER, J.C.; SMITH, P.; NORTON, M. (eds.) 2011. Interpreting Clifford Geertz: Cultural Investigations in the Social Sciences. Palgrave Macmillan, 2011.

11. ANDERSON, E. The Iconic Ghetto. In: ANDERSON, E. et al. Bringing Fieldwork Back In: Contemporary Urban Ethnographic Research. The Annals of the American Academy of Political and Social Science, v. 642. Sage Publications, Inc., 2012.

12. ANDERSON, E. The White Space. Sociology of Race and Ethnicity, v. 1, n., pp. 10-21, 2015.

13. APTER, D.E.; SAICH, T. Revolutionary Discourse in Mao's Republic. Cambridge, MA: Harvard University Press, 1994.

14. ARON, H. These Savvy Women Have Made Black Lives Matter The Most Crucial Left-Wing Movement Today. LA Weekly, 9 Nov 2015. Acessado em 1 Mar 2016 (htpp://www.laweekly.com/news/these-savvy-women-have-made-blacklives-matter-the-most-crucial-left-wing-movement-today-6252489.

15. ASSOCIATED PRESS. Thousands protest nationally after Ferguson grand jury decision, more protests planned. 24 Nov, 2014. Acessado em 17 Jul 2016. http:// www.nola.com/crime/index.ssf/2014/11/national_ferguson_protest_mike.html. 
16. BAUMAN, M.K.; KALIN, B. (Eds). The Quiet Voices: Southern Rabbis and Black Civil Rights, 1880s to 1990s. Tuscaloosa, Alabama: University of Alabama Press, 2014.

17. BELLAH, R.N. Civil Religion in America. In: BELLAH, R. (ed.) Beyond Belief, pp. 168-189. New York: Harper and Row, 1970.

18. BRANCH, T. Parting the Waters: America in the King Years, 1954-63. New York: Simon and Schuster, 1988.

19. BURKE, E. A Philosophical Enquiry. Oxford: Oxford University Press, [1757] 1990.

20. CAMPBELL, W.D. And Also with You: Duncan Gray and the American Dilemma. Franklin, TN: Providence House Publishers, 1997.

21. CHAPPELL, D. Inside Agitators: White Southerners in the Civil Rights Movement. Baltimore: Johns Hopkins University Press, 1994.

22. CHEN, Y-F. Making Revolution: The Communist Movement in Eastern and Central China, 1937-1945. Berkeley: University of California Press, 1986.

23. CHOZICK, A. Mothers of Black Victims Emerge as a Force for Hillary Clinton. New York Times, 13 Abril, 2016a. Acessado 17 Jul 2016. http://nyti.ms/1qoblen.

24. CHOZICK, A. Bill Clinton Says He Regrets Showdown With Black Lives Matters Protesters. New York Times, 9 Abril, $2016 b$, p.A12.

25. COBB, J. The Matter of Black Lives. The New Yorker, Março 14, 2016, pp.33-40.

26. DUNEIER, M. Ghetto: The Invention of a Place, the History of an Idea. New York: FSG, 2016.

27. EDLES, L. Symbol and Ritual in the New Spain: The Transition to Democracy after Franco. New York: Cambridge University Press, 1998.

28. ELIGON, J. Activists Move From Street to Ballot, Emboldened by Protests. New York Times, Fevereiro, 7, 2016, p :A1.

29. ESKEW, G.T. But for Birmingham: The Local and National Movements in the Civil rights Struggle. Chapel Hill: University of North Carolina Press, 1997.

30. EYERMAN, R. Performing Opposition or, How Do Social Movements Move. In: ALEXANDER, J.C.; GIESEN, B.; MAST, J.L. [Eds.] Social Performance: Symbolic Action, Cultural Pragmatics, and Ritual, pp.193 - 217. New York: Cambridge University Press, 2006. 
31. FREELON, D.; MCILWAIN, C.D.; CLARK, M.D. Beyond the Hashtags: \#Ferguson, \#Blacklinesmatter, and the Online Struggle for Offline Justice. Center for Media and Social Impact, School of Communication, American University. Washington D.C. 29 Fev. 2016. Acessado em 17 Jul 2016. Disponível em: http://www. cmsimpact.org/sites/default/files/beyond_the_hashtags_2016.pdf.

32. GARROW, D. Nonviolence and Racial Justice. Christian Century, v.74, n.6, Fev, 1957, pp.165-167.

33. GARROW, D. Protest at Selma: Martin Luther King, Jr., and the Voting Rights Act of 1965. New Haven: Yale University Press, 1978.

34. GOODMAN, T. Staging Solidarity: Truth and Reconciliation in a New South Africa. New York: Routledge, 2016.

35. GRAMSCI, A. The Modern Prince and other Writings. Moscow: International Publishers, 1959.

36. HEALY, J.; STOLBERG, S.G.; YEE, V. Ferguson Report Puts 'Hands Up' to Reality Test. The New York Times, 6 Mar, 2015, p.A1.

37. HELSEL, P. 'Black Lives Matter' Activists Disrupt Bernie Sanders Speech. NBC News. 9 Ago, 2015. Acessado 17 Jul 2016. Disponível em: http://www. nbcnews.com/politics/2016-election/black-lives-mattr-activists-disrupt-berniesanders-speech-n406546.

38. HO, D.Y. The Power of Culture. The PRC History Review, v.1, n. 2, pp. 5-6, 2015.

39. HOWARD, G. DeRay Mckesson Won't Be Elected Mayor of Baltimore. So Why IS He Running? New York Times Magazine, 11 Abr, 2016. Acessado 17 Jul 2016. http://www.nytimes.com/2016/04/11/magazine/deray-mckessonwont-beelected-mayor-of-baltimore-so-why-is-he-running.html?emc=eta1\&_r=0

40. KANG, J.C. 'Our Demand Is Simple: Stop Killing Us.' New York Times Magazine, 4 Mai, 2015. Acessado 17 Jul 2016. http://www.nytimes.com/2015/05/10/ magazine/our-demand-is-simple-stop-killing-us.html.

41. KINDY, K. et al.. A Year of Reckoning: Police Fatally Shoot Nearly 1000. Washington Post, 26 Dez, 2015. Acessado 17 Jul 2016. Disponível em: http:// www.washington post.com/sf/investigative/2015/12/26/a-year-of-reckoning-police-fatally-shoot-nearly-1000/

42. KUTTNER, P. Black Symbols Matter. Cultural Organizing. 10 Ago., 2015. Acessado 17 Jul 2016. Disponível em: http://culturalorganizing.org/black-symbols-matter/

43. LANDRY, B.. The New Black Middle Class. Berkeley: University of California Press, 1988. 
44. LENIN, V. What Is to Be Done? New York: Bantam Books, [1902] 1966.

45. LENTZ, R. Symbols, the News Magazines, and Martin Luther King. Baton Rouge: Louisiana State University Press, 1990.

46. LITTLE, K.K. You Must Be from the North: Southern White Women in the Memphis Civil Rights Movement. Jackson, Mississippi: University of Mississippi Press, 2009.

47. McLAUGHLIN, M. The Dynamic History of \#BlackLivesMatter Explained: This Is How a Hashtag Transformed into a Movement. The Huffington Post, 29 Fev., 2016. Acessado 17 Jul 2016. http://www.huffingtonpost.com/entry/historyblack-lives-matter_us_56d0a3b0e4b0871f60eb4af5.

48. MASSEY, D.S.; DENTON. N.A. American Apartheid: Segregation and the Making of the Underclass. Cambridge: Harvard University Press, 1993.

49. MAST, J. The Performative Presidency: Crisis and Resurrection in the Clinton Years. New York: Cambridge University Press, 2012.

50. MCADAM, D. Political Process and the Development of Black Insurgency, 1930-70. Chicago: University of Chicago Press, 1982.

51. MEIER, A. On the Role of Martin Luther King. New Politics, v. 4, n. 1, 1965, pp.52-59.

52. MICHEL, G.L. Inside Agitators: White Southerners in the Civil Rights Movement. New York: Palgrave Macmillan, 2004

53. MILLER, J.T. 'Million Hoodie March' in New York Rallies Support for Trayvon Martin. Time, 22 Mar., 2012. Acessado 17 Jul 2016. Disponível em: http://newsfeed.time.com/2012/03/22/million-hoodie-march-in-new-york-rallies-supportfor-trayvon-martin/.

54. MOODY, A. Coming of Age in Mississippi - White Sympathizers and Supporters of the Civil Rights Movement. New York: Random House, 2011.

55. MOORE, D.C. Black Activists Are Literally Stealing the Stage from 2016 Contenders - And It's Working. Identities.Mic., 13 Ago., 2015a. Acessado 17 Jul 2016. http://mic.com/articles/123796/black-activists-called-out-bernie-sandersjeb-bush-hillary-clinton-and-martin-omalley\#.8ktXliucn.

56. MOORE, D.C. Two Years Later, Black Lives Matter Faces Critiques, But it Won't Be Stopped. Identities.Mic., 10 Ago., 2015b. Acessado 17 Jul 2016. http:// mic.com/articles/123666/two-years-later-black-lives-matter-faces-critiques-but-itwon-t-be-stopped\#.kE68fRkeH.

57. MORRIS, A.D. The Origins of the Civil Rights Movement: Black Communities Organizing for Change. New York: Free Press, 1984. 
58. MORRIS, A.D. Naked Power and The Civil Sphere. The Sociological Quarterly, v. 48, n. 4, pp.615-628, 2007.

59. MURPHY, S.A. Breaking the Silence: The Little Rock Women's Emergency Committee to Open Our Schools, 1958-1963. Fayetteville, Arkansas: University of Arkansas Press, 1997.

60. NEW YORK TIMES. A year After Gray's Arrest, 'Baltimore's Mind-Set Has Changed'. Abril 13, 2016, p.A18.

61. PATTERSON, O. Rituals of Blood. Washington D.C.: Civitas, 1998.

62. PAYNE, C.M. I've Got the Light of Freedom: The Organizing Tradition and the Mississippi Freedom Struggle. Berkeley: University of California Press, 1995.

63. PERRY, E.J. Moving the Masses: Emotion Work in the Chinese Revolution. Mobilization: An International Journal, v. 7, n. 2, pp.111-128, 2002.

64. PERRY, E.J. Anyuan: Mining China's Revolutionary Tradition. Berkeley: University of California Press, 2012.

65. PEW RESEARCH CENTER. Across Racial Lines, More Say Nation Needs to Achieve Racial Equality. 5 Ago., 2015. Acessado 17 Jul 2016. http://www.peoplepress.org/2015/08/05/across-racial-lines-more-say-nation-needs-to-make-changes-to-achieve-racial-equality/.

66. PUTNAM, R.D. Bowling Alone: The Collapse and Revival of American Community. New York: Simon and Schuster, 2000.

67. RAUER, V. Symbols in Action: Willy Brandt's Kneefall at the Warsaw Memorial. In: ALEXANDER, J.C.; GIESEN, B.; MAST, J.L. [Eds.] Social Performance: Symbolic Action, Cultural Pragmatics, and Ritual, pp. 257-282. New York: Cambridge University Press, 2006.

68. REED, I. Charismatic Performance: A Study of Bacon's Rebellion. American Journal of Cultural Sociology, v. 1, n. 2, pp.1-35, 2013.

69. ROBERTS, G.; KLIBANOFF, H.. The Race Beat: The Press, The Civil Rights Struggle, and the Awakening of a Nation. New York: Vintage, 2007.

70. ROBINSON, A.L.; SULLIVAN, P. [Eds.] New Directions in Civil Rights Studies. Charlotte, VA: University of Virginia Press, 1991

71. RUFFIN, H.G.N. Black Lives Matter: The Growth of a New Social Justice Movement. Blackpast.org. s/d. Acessado 17 Jul 2016. http://www.blackpast.org/ perspectives/black-lives-matter-growth-new-social-justice-movement.

72. SCHECHNER, R. Performance Studies: An Introduction. New York: Routledge, 2002. 
73. SHEAR, M. Obama Speaks Out on Trayvon Killing. New York Times, 23 Mar. 2012 Acessado 17 Jul 2016. http:/thecaucus.blogs.nytimes.com/2012/03/23/ obama-makes-first-comments-on-trayvon-martin-shooting/.

74. SIDNER, S.; SIMON, M. The Rise of Black Lives Matter: Trying to Break the Cycle of Violence and Silence. CNN.Com, 28 Dez. 2015. Acessado 17 Jul 2016. http://edition.cnn.com/2015/12/28/us/black-lives-matter-evolution/.

75. SMITH, P.; HOWE, N. Climate Change as Social Drama. New York: Cambridge University Press, 2015.

76. SNOW, E. Red Star Over China. New York: Random House. [1938] 2007. Acessado 17 Jul 2016. https://books.google.com/books?isbn=0802196101.

77. SOKOL, J. There Goes My Everything: White Southerners in the Age of Civil Rights, 1945-1975. New York: Vintage, 2006.

78. STOCKMAN, F. On Crime Bill and the Clintons, Young Blacks Clash With Parents. New York Times, 18 Abril, 2016, p.A1.

79. SULLIVAN, J. et al. In Fatal Shootings by Police, 1 in 5 Officers' Names Go Undisclosed. Washington Post, 1 Abril, 2016. Acessado 17 Jul 2016. https://www. washington post.com/investigations/in-fatal-shootings-by-police-1-in-5-officersnames-go-undisclosed/2016/03/31/4bb08bc8-ea10-11e5-b0fd-073d5930a7b7_ story.html.

80. SUN, F. Social Suffering and Political Confession: Suku in Modern China. Peking University Series on Sociology and Anthropology, vol. 1. World Scientific: Beijing, 2013.

81. TELESUR. 2014 Freedom Ride Arrives in Ferguson Today. 29 Ago., 2014. Acessado 17 Jul 2016. http://www.telesurtv.net/english/news/2014-FreedomRide-Arrives-in-Ferguson-Today-20140829-0032.html.

82. TERRILL, R. The White Boned Demon: A Biography of Madame Mao Zedong. New York: William Morrow, 1984.

83. WILSON, W.J. The Truly Disadvantaged: The Inner City, the Underclass, and Public Policy. Chicago: University of Chicago Press, 1987.

84. WOODS, E.T. The Long Road to Apology: A Cultural Sociology of the Anglican Mission and the Indian Residential School in Canada. New York: Palgrave, 2016.

85. WU, G. Recalling Bitterness: Historiography, Memory, and Myth in Maoist China. Twentieth-Century China, v. 39, n. 3, pp.245-268, 2014. 
86. ZEDONG, M. Talks at the Yenan Forum on Literature and Art. 2 Maio, 1942. Acessado 17 Jul 2016. https://www.marxists.org/reference/archive/mao/ selected-works/volume-3/mswv3_08.htm.

87. ZILLGIT, J.; STRAUSS, C. Protests Greet Prince William and Kate at CavaliersNets. USA Today. 9 Dez., 2014. Acessado 17 Jul 2016. http://www.usatoday.com/ story/sports/nba/2014/12/08/cavaliers-nets-protests-william-kate-lebron-james-icant-breathe-shirts/20122331/

Recebido: 26.10.2016

Aceito: 15.12 .2016 